\title{
Self-organized formation of spherical porous granules only by one-step heat-treatment in $\mathrm{MgO}-\mathrm{Fe}_{2} \mathrm{O}_{3}-\mathrm{Nb}_{2} \mathrm{O}_{5}$ system
}

\author{
Yoshikazu Suzuki, ${ }^{a^{*}}$ Hiroko Tokoro ${ }^{a}$ and Hiroya Abe ${ }^{b}$ \\ ${ }^{a}$ Faculty of Pure and Applied Sciences, University of Tsukuba, 1-1-1 Tennodai, Tsukuba, Ibaraki, \\ 305-8573, Japan \\ ${ }^{\mathrm{b}}$ Joining and Welding Research Institute, Osaka University, 11-1 Mihogaoka, Ibaragi, Osaka \\ 567-0047, Japan
}

\begin{abstract}
In this letter, a new process to obtain spherical porous granules (SPGs) is presented, namely self-organized formation only by a one-step heat-treatment. Commercial $\mathrm{MgCO}_{3}$ (basic), $\alpha-\mathrm{Fe}_{2} \mathrm{O}_{3}$ and $\mathrm{Nb}_{2} \mathrm{O}_{5}$ powders of $\mathrm{Mg}: \mathrm{Fe}: \mathrm{Nb}=1: 1: 1$ in mole fraction were wet-ball milled, and were heat-treated in air at $800-1350^{\circ} \mathrm{C}$. The samples heated at $\geq 1100^{\circ} \mathrm{C}$, most of the samples became SPGs with the diameter of $\sim 50-100 \mu \mathrm{m}$, containing 3-D network structure. The main constituent phase of porous spheres was pseudobrookite- type $\mathrm{MgFeNbO}_{5}$. The formation mechanism of porous microspheres was discussed by using SEM observation and high-temperature XRD analysis.
\end{abstract}

Keywords: porous spheres, granular materials, self-organization, pseudobrookite, $\mathrm{MgFeNbO}_{5}$

\section{Introduction}

Porous ceramics are widely used for fluid filters, catalysts, catalyst supports, lightweight structural materials, and so on. Among various shapes of the porous ceramics, spherical porous granules (SPGs) are favorable for heterogeneous catalysts, photonic materials, chromatography supports, drug delivery carriers, and healing of defective bones [1-4]. A variety of processes, mostly liquid-based, have been developed to synthesize SPGs [1, 5-15]. To synthesize SPGs, solid-based processes have seldom been realized, except the mechanical granulation method with rotating fluidized bed [16].

We developed uniformly porous ceramics with 3-D network structure (UPC-3D) by using pyrolytic reactive sintering of powder mixtures including gaseous spices such as carbonates and hydroxides [17,18]. Stimulated by Bayer's [19] early report in 1971 on pseudobrookite-type ceramics (generally expressed as $\mathrm{Me}_{3} \mathrm{O}_{5}$ ), uniformly porous $\mathrm{MgTi}_{2} \mathrm{O}_{5}$ [20-21], and its derivative, bulk $\mathrm{MgFeNbO}_{5}\left(\mathrm{Fe}^{3+}+\mathrm{Nb}^{5+}\right.$ substitute $\left.2 \mathrm{Ti}^{4+}\right)$ have recently been synthesized [22]. In this previous report on bulk $\mathrm{MgFeNbO}_{5}$ [22], mold-pressed compacts of mortar-mixed powders of $\mathrm{MgCO}_{3}$ (basic), $\alpha-\mathrm{Fe}_{2} \mathrm{O}_{3}$ and $\mathrm{Nb}_{2} \mathrm{O}_{5}$ were sintered in air to obtain relatively dense materials. However, when the ball-milled powder mixture was simply heated in air, we have found the self-organized formation of

\footnotetext{
* Corresponding Author

E-mail: suzuki@ims.tsukuba.ac.jp

Tel: +81-29-853-5026 / Fax: +81-29-853-4490
} 
SPGs, mainly composed of $\mathrm{MgFeNbO}_{5}$ phase. Here we present the new process to synthesize SPGs only by one-step heat-treatment in the $\mathrm{MgO}-\mathrm{Fe}_{2} \mathrm{O}_{3}-\mathrm{Nb}_{2} \mathrm{O}_{5}$ system.

\section{Experimental}

$\mathrm{MgCO}_{3}$ (basic) $\left(\mathrm{Mg}_{5}\left(\mathrm{CO}_{3}\right)_{4}(\mathrm{OH})_{2} \bullet 4 \mathrm{H}_{2} \mathrm{O}, 99.9 \%\right.$, Kojundo Chemical Laboratory), $\alpha-\mathrm{Fe}_{2} \mathrm{O}_{3}$ and $\mathrm{Nb}_{2} \mathrm{O}_{5}$ (99.9\% each, Wako Pure Chemical Ind.) powders were used as the starting materials, similar to the previous report [22]. The $\mathrm{MgCO}_{3}$ (basic), $\alpha-\mathrm{Fe}_{2} \mathrm{O}_{3}$ and $\mathrm{Nb}_{2} \mathrm{O}_{5}$ powders $(\mathrm{Mg}: \mathrm{Fe}: \mathrm{Nb}=$ 1:1:1 in mole fraction) were wet-ball milled for $24 \mathrm{~h}$ in ethanol with $\mathrm{ZrO}_{2}$ balls, dried and sieved through 100 mesh screen $(<150 \mu \mathrm{m})$. The mixed powder was heated at the ramp rate of $10^{\circ} \mathrm{C} / \mathrm{min}$, up to the maximum temperatures from 800 to $1350^{\circ} \mathrm{C}$, and then cooled to room temperature without holding time. For the precise temperature control, TG-DTA apparatus is useful, but normal air furnaces can also be used.

The microstructure of the heat-treated products was characterized by scanning electron microscopy (SEM, SU-70, Hitachi High-Tech.) and digital optical microscopy (VHX-1000, Keyence Co.). The reaction behavior of the $\mathrm{MgCO}_{3}$ (basic) $-\mathrm{Fe}_{2} \mathrm{O}_{3}-\mathrm{Nb}_{2} \mathrm{O}_{5}$ mixed powder (without compressing) was analyzed by high-temperature X-ray diffraction (HT-XRD, Multiflex, $\mathrm{Cu}-\mathrm{K}_{\alpha}, 40$ $\mathrm{kV}$ and $40 \mathrm{~mA}, \mathrm{XRD}$, Rigaku), from room temperature to $1350^{\circ} \mathrm{C}$ in air. Diffraction patterns were acquired at $100^{\circ} \mathrm{C}$ each up to $1000^{\circ} \mathrm{C}$, and $50^{\circ} \mathrm{C}$ each up to $1350^{\circ} \mathrm{C}$. The ramp rate of the furnace was $10^{\circ} \mathrm{C} / \mathrm{min}$. XRD patterns were acquired after $5 \mathrm{~min}$ holding at each temperature. The scanning rate was $2 \theta=4 \%$ min and the scanning range was $2 \theta=10-60^{\circ}$, hence, 5 min holding +15 min scanning at each temperature.

\section{Results and discussion}

Fig. 1 shows representative SEM images of (a) the $\mathrm{MgCO}_{3}$ (basic)- $\alpha-\mathrm{Fe}_{2} \mathrm{O}_{3}-\mathrm{Nb}_{2} \mathrm{O}_{5}$ mixed powder and (b) its heat-treated-only product (SPGs) at $1350^{\circ} \mathrm{C}$ (ramp speed: $10^{\circ} \mathrm{C} / \mathrm{min}$, holding time: $0 \mathrm{~min}$ ), and (c) a digital optical microscope image (real color) of SPGs. The microstructure was drastically changed only by the simple heating. In order to verify the microstructure development during the heating, Fig. 2 shows lower magnification SEM images of the heat-treated products at $800-1300^{\circ} \mathrm{C}$. To prepare the SEM samples, heat-treated products were spread on a carbon tape using a spatula, and coated with Pt by sputtering. At $800^{\circ} \mathrm{C}$, the surface of fine particles reflected the sample preparation with a spatula (i.e., like spread butter with a butter knife), but special structural feature was not observed. At $900^{\circ} \mathrm{C}$, a part of fine particles started to form SPGs with the diameter of $\sim 50 \mu \mathrm{m}$. At $1000^{\circ} \mathrm{C}$, formation of SPGs became frequent. The spherical granules seem to be soft due to the weak bonding among primary particles, because the surface of some granules was slightly flattened by the sample preparation. At $>1100^{\circ} \mathrm{C}$, most of the sample became SPGs, with typical diameter of $\sim 50-100 \mu \mathrm{m}$. 
Mater. Lett.

2015.7.1

1

2

3

4

5

7

8

10

11

12

13

14

15

16

17

18

19

20

21

22

23

24

25

26

27

28

29

30

31

32

33

34

35

36

37

38

39

40

41

42

43

44

45

46

47

48

49

50

51

52

53

54

55

56

57

58

59

60

61

62

63

64

65
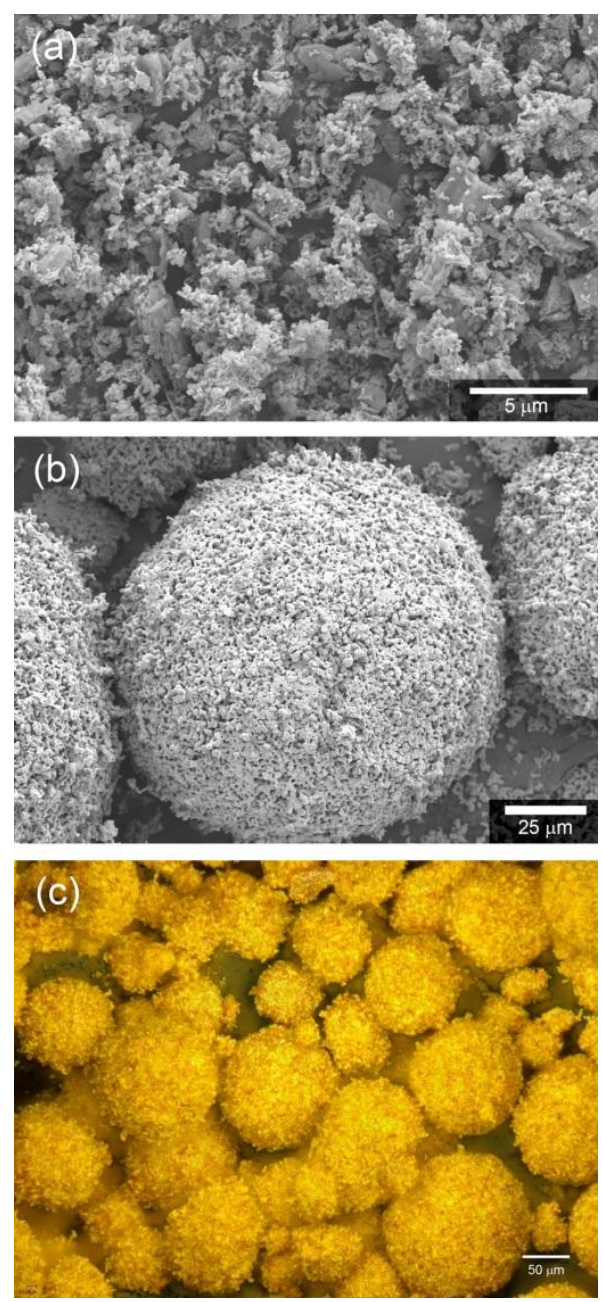

Fig. 1
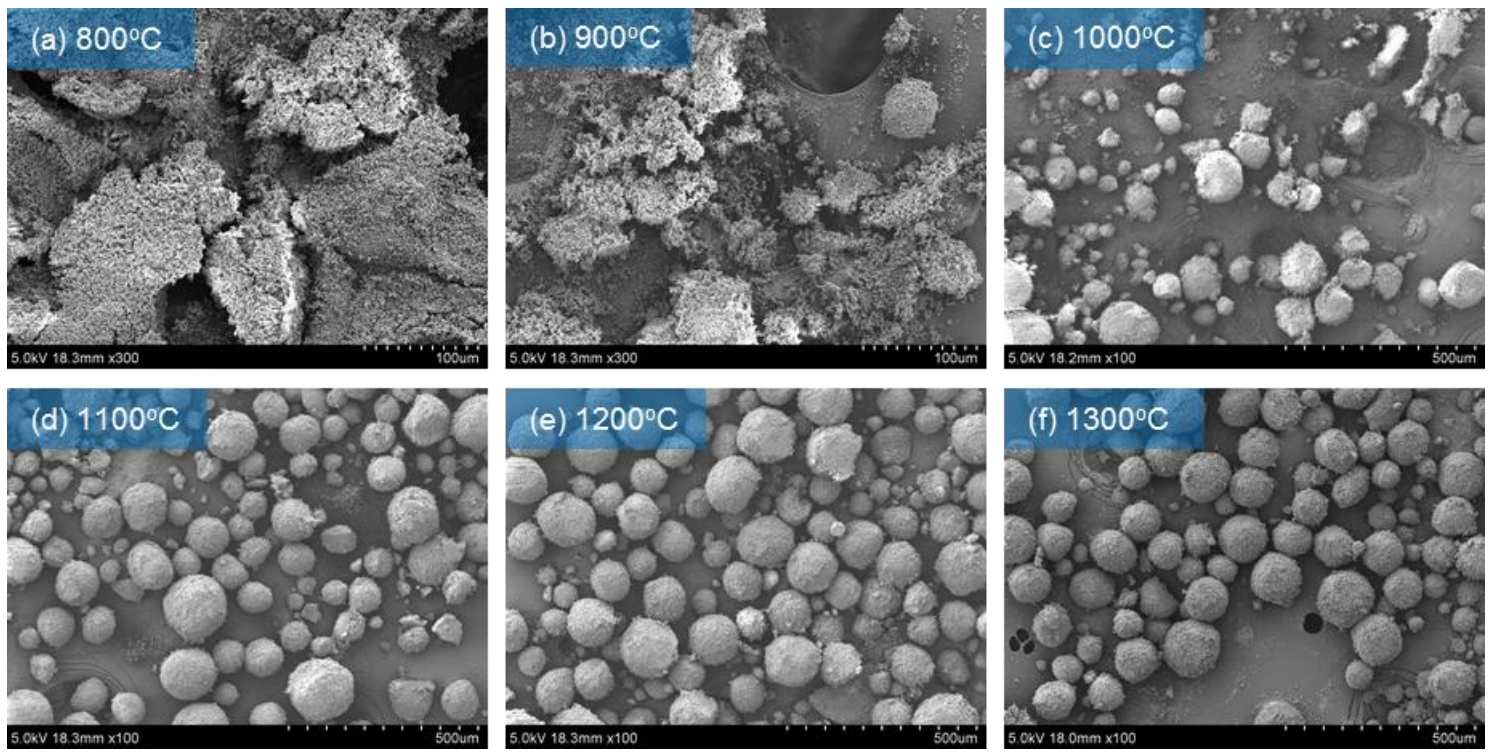

Fig. 2 
Figure 3 shows higher magnification SEM images of the heat-treated products from the $\mathrm{MgCO}_{3}$ (basic) $-\alpha-\mathrm{Fe}_{2} \mathrm{O}_{3}-\mathrm{Nb}_{2} \mathrm{O}_{5}$ mixed powder. At $800^{\circ} \mathrm{C}$, the microstructure was similar to that of the as-mixed powder at room temperature (Fig. 1(a)), however, at $900^{\circ} \mathrm{C}$, the primary particles start to connect to each other. Somewhat large and rod-like grains observed at $800-1000^{\circ} \mathrm{C}$ are attributed to the pseudomorphs (remnants of original shape) consisted of fine $\mathrm{MgO}$ particles from hydromagnesite. At $\geq 1100^{\circ} \mathrm{C}$, curved and so-called "L-shaped" grains were observed, which are typically found in pseudobrookite-type ceramics with some liquid phase [20-22], and necking between particles became firmer. At $1300^{\circ} \mathrm{C}$, although some grains with intermediate clombite-type and spinel-type structures remained at the surface, most of the product converted into pseudobrookite-type $\mathrm{MgFeNbO}_{5}$.
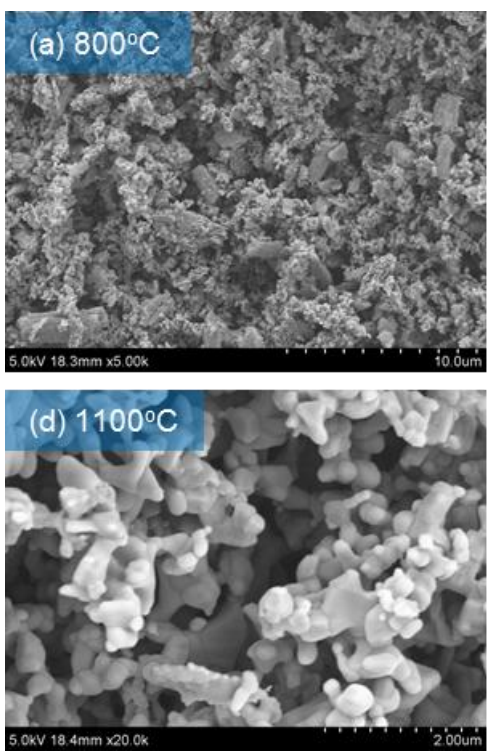
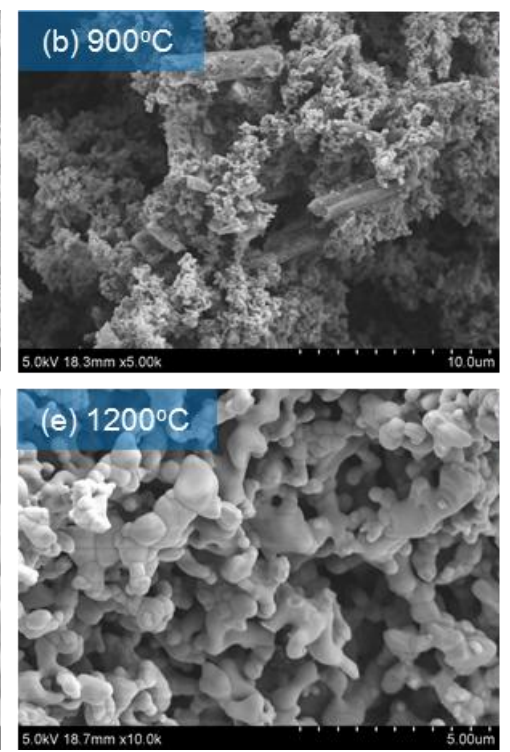

Fig. 3
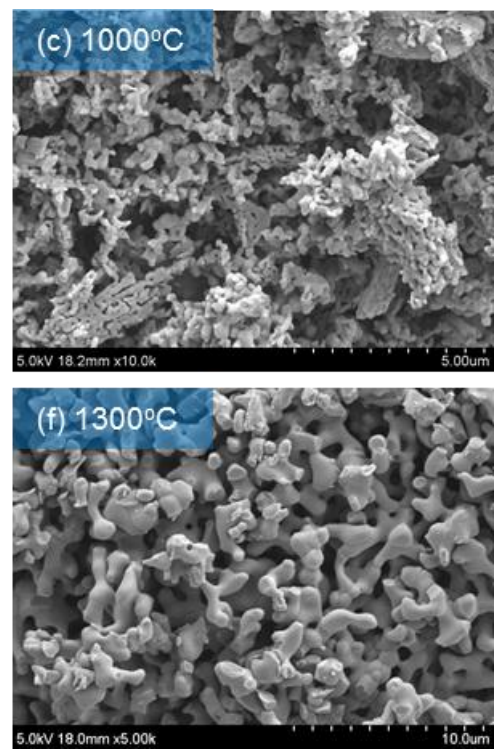

The reaction behavior of the $\mathrm{MgCO}_{3}$ (basic) $-\alpha-\mathrm{Fe}_{2} \mathrm{O}_{3}-\mathrm{Nb}_{2} \mathrm{O}_{5}$ mixed powder during the heat-treatment was analyzed by HT-XRD as shown in Fig. 4. All peaks before heating were well-indexed with $\mathrm{Mg}_{5}\left(\mathrm{CO}_{3}\right)_{4}(\mathrm{OH})_{2} \bullet 4 \mathrm{H}_{2} \mathrm{O}$ (hydromagnesite, ICDD PDF \#25-0523), $\alpha-\mathrm{Fe}_{2} \mathrm{O}_{3}$ (hematite, \#33-0664), and low-temperature phase $\mathrm{Nb}_{2} \mathrm{O}_{5}$ (\#27-1003). The thermal decomposition of hydromagnesite completed at $\sim 500^{\circ} \mathrm{C}$ (comfirmed by TG-DTA, Fig S1), and $\mathrm{MgO}$ nanocrystals was formed from hydromagnesite as shown in Fig. 4. As shown in Fig. 3, $\mathrm{MgO}$ nanocrystals kept the pseudomorphs of hydromagnesite at intermediate temperatures $\left(\sim 500-800^{\circ} \mathrm{C}\right)$. At $\sim 900-1000^{\circ} \mathrm{C}$, the formation of intermediate clombite-type $\mathrm{MgNb}_{2} \mathrm{O}_{6}$ (ss) and spinel-type $\mathrm{MgFe}_{2} \mathrm{O}_{4}$ (ss) phases started. At $\sim 1100^{\circ} \mathrm{C}$, the formation of pseudobroolkite-type $\mathrm{MgFeNbO}_{5}$ started. At $1300^{\circ} \mathrm{C}$, pseudobroolkite-type $\mathrm{MgFeNbO}_{5}$ became preferential, and at $1350^{\circ} \mathrm{C}$, the intermediate phases were almost disappeared (corresponding to Fig. 1(b)). After a certain holding time at a high temperature 
(e.g., $1350^{\circ} \mathrm{C}$ for $2 \mathrm{~h}$ ), the porous spheres started to sinter. Fig. S2 shows a SEM image of the sample after a series of HT-XRD measurements (measurements at each temperature, including final measurement at $1350^{\circ} \mathrm{C}$ with $2 \mathrm{~h}$ holding), corresponding to the sample after cooling in Fig. 4. Spinel grains with octahedral facets were sometimes observed at the surface of semi-sintered porous spheres. That is why spinel 111 peak at $2 \theta=18.3^{\circ}$ is stronger than spinel 311 peak around $35^{\circ}$ (usual strongest peak) in the top pattern of Fig. 4 .

From the microstructural observation (Figs. 1-3 and S2) and HT-XRD analysis (Fig. 4), the self-organized porous microsphere formation can be attributed to (1) local liquid phase formation by multiphase eutectic reactions at high temperatures and (2) limited sinterability of anisotropic pseudobrookite-type grains. The upper size limitation of the porous spheres might be related to the mesh screen size $(<150 \mu \mathrm{m})$ used in the powder process, although the agglomerate was very soft as shown in Figs. 1(a) and 2(a). The local liquid-phase formation promoted the granulation and sphericalization of fine particles to reduce the surface energy. In addition, due to the limited sinterability of pseudobrookite phase, it kept the 3-D network structure up to relatively high temperature of $1350^{\circ} \mathrm{C}$. Although only a specific system $\left(\mathrm{MgO}-\mathrm{Fe}_{2} \mathrm{O}_{3}-\mathrm{Nb}_{2} \mathrm{O}_{5}\right)$ was presented in this study, similar processing can be extended for the pyrolytic reactive sintering in other systems with satisfying above two conditions. In the future, we will clarify the granulation and sphericalization mechanism in detail by using in situ observation techniques, and will functionalize the microspheres for catalysts and so on.

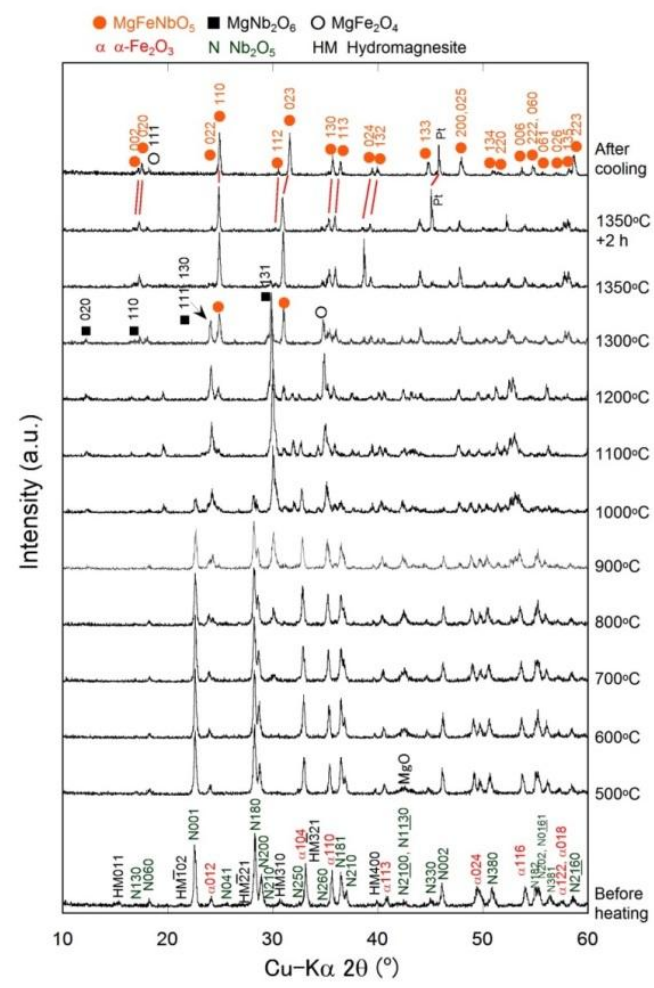

Fig. 4 


\section{Conclusions}

In this report, self-organized formation of spherical porous granules (SPGs) in $\mathrm{MgO}-\mathrm{Fe}_{2} \mathrm{O}_{3}-\mathrm{Nb}_{2} \mathrm{O}_{5}$ system was presented. Only by the heat-treatment of the $\mathrm{MgCO}_{3}$ (basic)- $\alpha-\mathrm{Fe}_{2} \mathrm{O}_{3}-\mathrm{Nb}_{2} \mathrm{O}_{5}$ mixed powder, SPGs with 3-D network structure, typically 50-100 $\mu \mathrm{m}$ in diameter, were obtained. The mechanism of porous sphere formation is probably attributable to (1) local liquid phase formation by multiphase eutectic reactions and (2) limited sinterability of anisotropic pseudobrookite-type grains.

\section{Acknowledgments}

This work was supported by (1) Grant-in-Aid for Science Research No. 23350111 for Basic Research: Category B, (2) Joint Research Project of JWRI, Osaka University, and (3) JST/ACT-C Project head by Prof. Junji Nakamura.

\section{References}

[1] Chang HW, Okuyama K. J Aerosol Sci 2002;33:1701-1702.

[2] Paul W, Sharma CP. J Mater. Sci Mater Med 1999; 10: 383-388.

[3] Komlev VS, Barinov SM, Orlovskii VP, Kurdyumov SG. Refract Ind Ceram 2001;42:195-197.

[4] Komlev VS, Barinov SM, Koplik EV. Biomater 2002;23:3449-3454.

[5] Jean G, Sciamanna V, Demuynck M, Cambier F, Gonon M. Ceram Int 2014;40:10197-10203.

[6] Garcia E, Mesquita-Guimarães J, Miranzo P, Osendi MI. Surf Coat Tech 2011;205:4304-4311.

[7] Terada Y, Suzuki Y, Tohno S. Mater Res Bull. 2012;47:889-895.

[8] Matsubara T, Suzuki Y, Tohno S. Comptes Rendus Chimie 2013;16: 244-251.

[9] Tallon C, Moreno R, Isabel Nieto M. Mater Res Bull. 2006;41:1520-1529.

[10] Paul F, Binder JR, Gesswein H, Ritzhaupt-Kleissl HJ, Hausselt J. Ceram Int 2008;35:479-486.

[11] Shepeleva MN, Shkrabina RA, Fenelonov VB, Ismagilov ZR. Appl Catal. 1991;78:175-184.

[12] Deng SG, Lin YS. AIChE J 1997;43:505-514.

[13] Nakamura YK, Murakami TN, Iwata NY, Hirano Y, Tokuoka Y, Kawashima N. J Ceram Soc Jpn. 2004;112:133-137.

[14] Han Y, Kim S, Kim H, Park J. J Am Ceram Soc. 2011;94:2742-2751.

[15] Ribeiro CC, Barrias CC, Barbosa MA. J Mater Sci Mater Med. 2006; 17:455-463.

[16] Watano S, Imada Y, Hamada K, Wakamatsu Y, Tanabe Y, Dave RN, Pfeffer R. Powd Tech. 2003;131:250-255.

[17] Suzuki Y, Morgan PED, Ohji T. J Am Ceram Soc. 2000;83:2091-2093.

[18] Suzuki Y, Kondo N, Ohji T, Morgan PED. Int J Appl Ceram Tech. 2004;1:76-85.

[19] Bayer G. J Less Common Metal. 1971;24:129-138.

[20] Suzuki Y, Morimoto M. J Ceram Soc Jpn. 2010;118:1212-1216.

[21] Suzuki Y, Suzuki TS, Shinoda Y, Yoshida K. Adv Eng Mater. 2012;14:1134-1138.

[22] Suzuki Y, Abe H. IOP Conf Ser Mater Sci Eng. 2014;54:no.012011. 


\section{Figure Captions}

Fig. 1 SEM images of (a) the $\mathrm{MgCO}_{3}$ (basic)- $\alpha-\mathrm{Fe}_{2} \mathrm{O}_{3}-\mathrm{Nb}_{2} \mathrm{O}_{5}$ mixed powder and (b) its heat-treated-only product (SPGs) at $1350^{\circ} \mathrm{C}$; (c) digital optical microscope image of SPGs.

Fig. 2 Lower magnification SEM images of the heat-treated products from the $\mathrm{MgCO}_{3}$ (basic)$\alpha-\mathrm{Fe}_{2} \mathrm{O}_{3}-\mathrm{Nb}_{2} \mathrm{O}_{5}$ mixed powder.

Fig. 3 Higher magnification SEM micrographs of the heat-treated products from the $\mathrm{MgCO}_{3}$ (basic)$\alpha-\mathrm{Fe}_{2} \mathrm{O}_{3}-\mathrm{Nb}_{2} \mathrm{O}_{5}$ mixed powder.

Fig. $4 \mathrm{HT}-\mathrm{XRD}$ patterns for the $\mathrm{MgCO}_{3}$ (basic)- $\alpha-\mathrm{Fe}_{2} \mathrm{O}_{3}-\mathrm{Nb}_{2} \mathrm{O}_{5}$ mixed powder. $\mathrm{Mg}$ : $\mathrm{Fe}: \mathrm{Nb}$ was 1:1:1 in mole fraction. The top pattern was taken at room temperature after cooling. Patterns at $100^{\circ}$, $200^{\circ}, 300^{\circ}, 400^{\circ}, 1050^{\circ}, 1150^{\circ}$ and $1250^{\circ} \mathrm{C}$ are not shown here. 


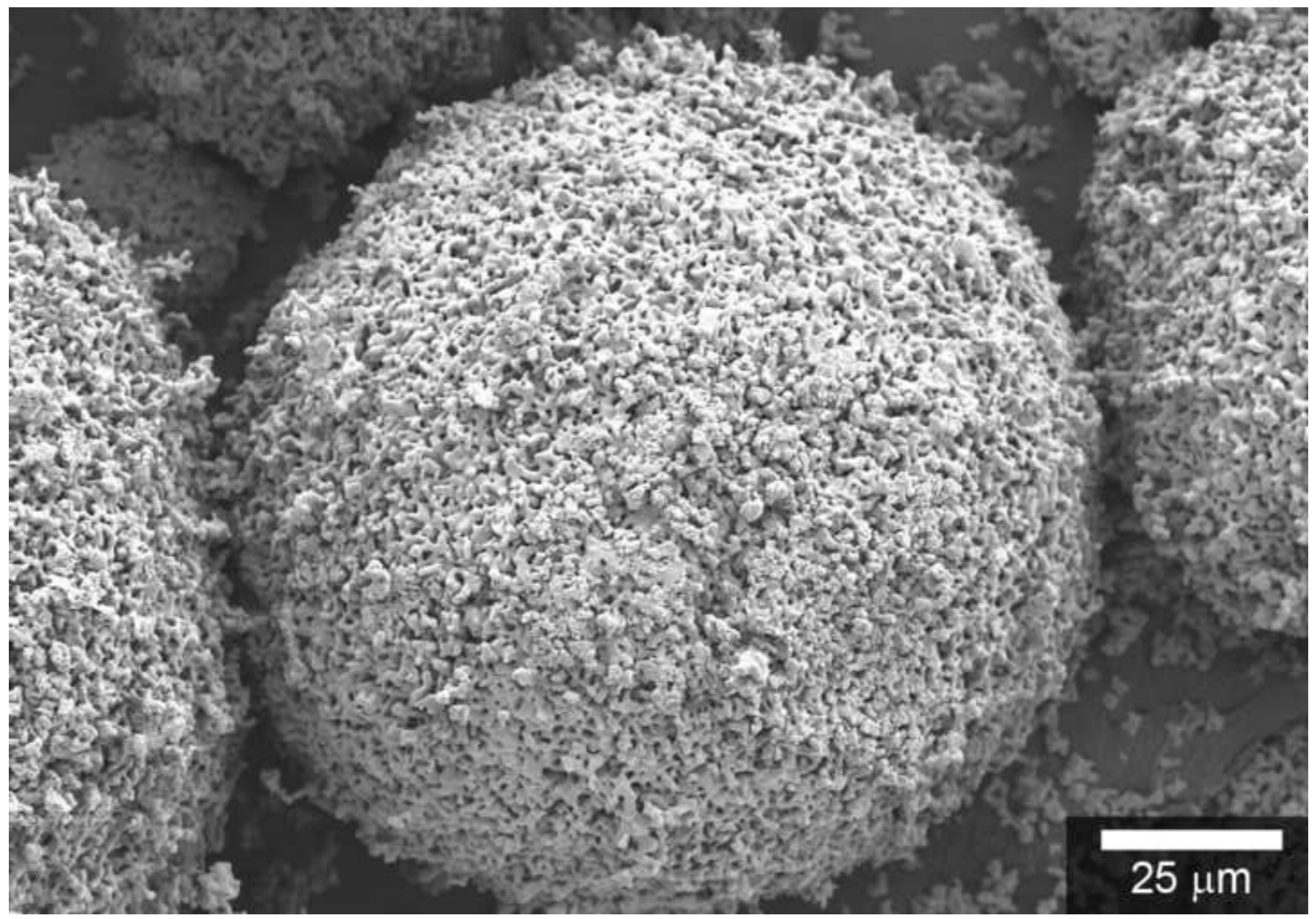

Whe

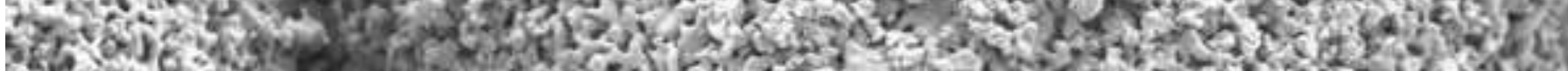

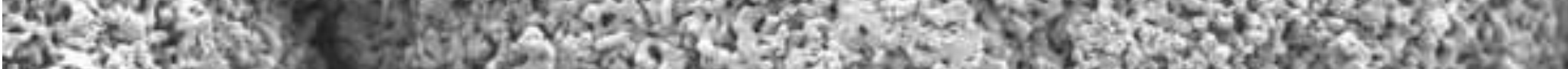

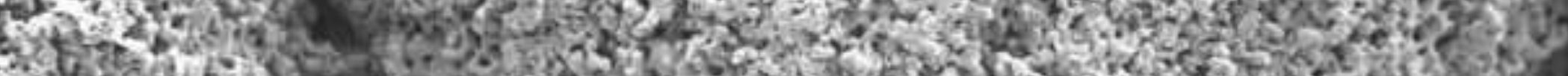

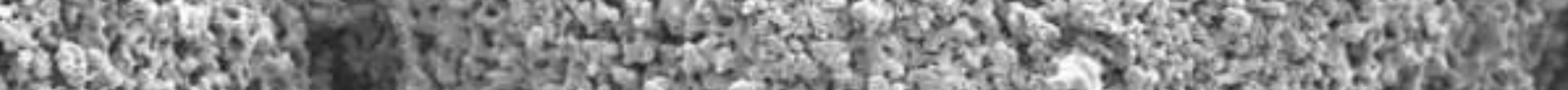

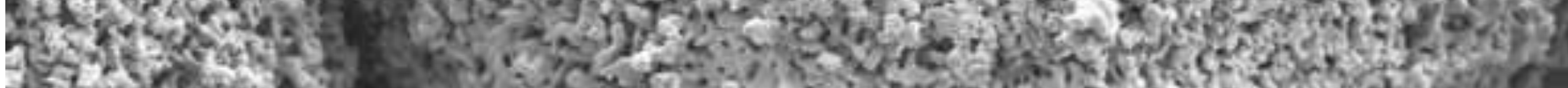


of 20,65 sexploysis

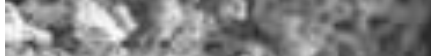

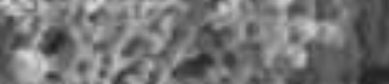

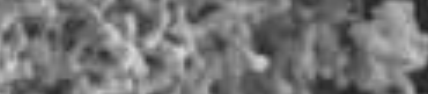

